\title{
Design Principles for Business-Model-based Management Methods-A Service-dominant Logic Perspective
}

\author{
Conference Paper · May 2017
}

CITATIONS

0

4 authors:

Michael Blaschke

University of St.Gallen

5 PUBLICATIONS 5 CITATIONS

SEE PROFILE

\section{Uwe V. Riss}

SAP (Switzerland) AG

65 PUBLICATIONS 1,145 CITATIONS

SEE PROFILE
READS

74
M. Kazem Haki

University of St.Gallen

32 PUBLICATIONS 77 CITATIONS

SEE PROFILE

Stephan Aier

University of St.Gallen

157 PUBLICATIONS 1,362 CITATIONS

SEE PROFILE

Some of the authors of this publication are also working on these related projects: 


\title{
Design Principles for Business-Model-based Management Methods-A Service-Dominant Logic Perspective
}

\author{
$\underline{\text { Michael Blaschke }}^{1,2(\bowtie)}, \underline{\text { M. Kazem Haki }}{ }^{1}, \underline{\text { Uwe Riss }}^{2}$, \\ 1 Institute of Information Management, \\ University of St. Gallen, St. Gallen, Switzerland \\ \{michael.blaschke, kazem. haki, stephan.aier\}@unisg.ch \\ 2 SAP Research and Innovation Hub, \\ SAP Switzerland Inc., St. Gallen, Switzerland \\ \{uwe.riss,michael.blaschke\}@sap.com
}

\begin{abstract}
Extant research gives rise to the notion of business-model-based management that stresses the pivotal role of the business model concept in organizational management. This role entails a shift in research from predominantly examining business model representation to the use of the business model concept in the design of management methods. In designing respective management methods, managers need to not only account for the business model concept, but also consider the characteristics of the emerging business environments in which business models are devised. To this, our study guides the design of business-model-based management methods through exploiting service-dominant logic, a theoretical lens that conceptualizes the emerging business environment. By means of design science research, this study develops four design principles for business-model-based management methods namely, ecosystem-, technology-, mobilization-, and co-creation-oriented management. This study also articulates the principles' rationale and implications and discusses their contribution in achieving business-model-based management.
\end{abstract}

Keywords: Design principles $\cdot$ Business model $(\mathrm{BM}) \cdot$ Business-model-based management $(B M B M) \cdot$ Service-dominant $($ S-D) logic $\cdot$ Design science research (DSR)

\section{Introduction}

"The rise of globe-spanning service-based business models has transformed the way the world works" [1, p. 665].

Seminal marketing studies [2-4] highlight a paradigmatic shift in economic exchange from a goods-dominant (G-D) to a service-dominant (S-D) logic. S-D logic moves the spotlight of economic exchange and value creation from a single organization to a broader actor-to-actor network-comprising competitors, suppliers, partners, regulators, and customers - in which an organization operates (network-centric focus). Moreover, S-D logic stresses that tangible goods (products and services) are no longer 
the sole object of exchange, but also associated or stand-alone intangible offerings in which the extent of information content is high (information-centric focus). In addition, S-D logic emphasizes a shift in the outcome of economic exchange, from features and attributes of goods to the value that is co-created (experience-centric focus) [5]. Pivotal to S-D logic is that value is determined by the quality of a value-in-use experience and not by the quality of goods' value-in-exchange [6, 7]. For instance, Hilti, a global market leader for professional drilling and mounting technologies, has initiated its shift to S-D logic with a first step of selling drilling equipment utilization (value-in-use, S-D logic) instead of selling drilling equipment (value-in-exchange, G-D logic).

The shift from G-D to S-D logic requires re-thinking the way economic exchange is executed and eventually the way value for customers is co-created. Therefore, while realizing such a shift, the most immediate and fundamental effect in organizational practice is on an organization's business model (BM). BMs conceptualize the core business logic of an organization describing the rationale of how an organization creates, proposes, delivers, and captures value [8]. For instance, Swiss Federal Railways has started re-arranging its BM to become a mobility service integrator instead of a mere mobility service provider. As such, instead of providing station-to-station service, it offers a door-to-door mobility service through orchestrating the mobility ecosystem in a network of various mobility providers. This endeavour requires understanding, designing, and managing actor-to-actor and service-based BMs, which has become a strategic imperative and focal subject for managing organizations [1, 9-11].

The study at hand investigates the design of business-model-based management (BMBM) $[12,13]$ methods to achieve the above-discussed shift. These methods use the BM concept to structure organizational units and actors, employ the boundaryspanning aspects of the BM concept (i.e., provider and customer interfaces), and align operations within and across organizations $[12,13]$. Our study is in fact motivated by the lack of guidance on designing BMBM methods. Our research hence seeks to answer the following question: What are design principles guiding the design of $B M B M$ methods to eventually account for and realize an $S$-D logic?

Even though prevalent BM research lays emphasis on uncovering the $B M$ concept/terminology [14], BM structure [15], and BM management process [16], guidance on the design of BMBM methods is lacking [17]. To this end and owing to S-D logic's distinctive conceptualization on value co-creation, we employ S-D logic as a kernel theory [2-4] and derive a set of design principles for BMBM methods.

The remainder of this paper is structured as follows. Section 2 presents the state-of-the-art of BM research and the theoretical background of S-D logic. Section 3 explicates the employed research methodology and its instantiated activities. Section 4 reports the four design principles offered to guide the design of BMBM methods. Section 5 discusses the developed principles and provides concluding remarks. 


\section{Research Background}

In seeking for drawing on and integrating in the extant business model (BM) and service-dominant (S-D) logic research, in this section we briefly synthesize existing knowledge and position our study.

\subsection{State-of-the-Art: The Business Model Concept}

Management research and practice has witnessed an ever-growing interest in the BM concept and perspective whose unique properties and effects are becoming fundamental in understanding and guiding organizational management [17]. Even though definitions still vary, extant research has adopted the notion of BM as a way of grasping the core business logic of an organization and describing its rationale in creating, proposing, delivering, and capturing value [8]. As such, management research theorizes the BM concept as an emerging unit of analysis that emphasizes a system-level, holistic approach to explain how organizations "do business" [14]. Prevalent BM research mainly lays emphasis on the BM concept/terminology (i.e., definitions and scope) [14], $B M$ structure (i.e., forms, components, value system, actors and interaction, and innovation) [15], and BM management process (i.e., design, implementation, operation, change and evolution, performance and controlling) [16].

The BM concept/terminology has been predominantly investigated in IS research so that IS scholars discuss the concept's broad diversity as well as ambiguity of its understandings, uses, and positions in the organization [18, 19]. More recently, IS research has shed light on the BM concept in various IS phenomena such as BMs in IT industries and IT-enabled or digital BMs [20]. Regarding BM structure, IS research engages in the ongoing discourse on the BM's ontological constituents [19, 21]. A prominent example is Osterwalder et al.'s [19] proposition for an ontology to describe a BM. Peters et al. [21] also propose a morphological box for the analysis, description, and classification of IT-enabled service BMs. Regarding BM management process, IS research is particularly interested in frameworks for BM management [13], IT support for BM design and management [22], and the design of IT platform BMs [23].

Recently, management research has started underscoring the pivotal role of BM in the management of organizations [14, 17, 24-26]. Such a role-underserved in extant research [27]_-goes beyond understanding, designing, or managing a single or multiple BMs, which is predominant in the existing research discourses. Instead, it emphasizes the BM concept as a crucial perspective and a means to manage the entire organization. This novel role has been recently reflected on the notion of businessmodel-based management (BMBM) [12] as a way of developing management methods that draw on the BM concept to holistically plan, organize, direct, and control the structure and dynamics of an organization [13]. While organizations mainly leverage BMs in an innovation context to ensure the economic viability of new products and services $[1,22]$, the BM concept's potential to manage organizations over their entire life cycle [28] is widely ignored. As such, BMBM aims to adopt the BM concept in 
management methods to eventually guide practitioners in constructing and maintaining their organizations' business logic [12, 13].

We underscore the distinction between BM management and BMBM methods. While the former refers to designing and managing one or multiple BMs, the latter employs the BM concept as a means to manage an organization and to increase organizational performance. As such, BMBM methods are different from BM management in that BMBM methods (i) facilitate strategy implementation; (ii) employ the BM concept as a holistic, boundary-spanning management framework; (iii) structure organizations and their units guided by a BM representation; (iv) facilitate a common ground for communication; and (v) align different BMs vertically within organizations and horizontally across cooperating organizations to increase business success [12, 27]. Notwithstanding the relevance of BMBM methods, practitioners still struggle with designing such methods due to their novelty and ambiguity [12]. Therefore, the main outcome of this study is a set of design principles guiding the design of BMBM methods.

\subsection{Theoretical Background: A Service-Dominant Logic Perspective}

The notion of service is researched in both service science and S-D logic, both of which developed in parallel but independent from each other [29, 30]. They have in common the premise that value occurs when heterogeneous actors work together for mutual benefit, the key being orchestration of these actors for effective service provision $[1,30]$. However, while service science seeks to understand and design innovative services under abstract philosophical assumptions [31, 32], S-D logic seeks to establish a unified theoretical foundation as a potential perspective on service science [30]. Owing to their relevance, both service science and S-D logic are present in IS research. While service science has long been discussed and used in IS research [31, 33], IS scholars have recently started to introduce and employ S-D logic in investigating IS phenomena [5, 34]. We opt for S-D logic over service science since (i) it offers a penetrative conceptualization of the emerging business environments in which BMBM methods are devised; and (ii) it provides a well-defined and unified theoretical basis through which the design of BMBM methods can be informed and guided.

$\mathrm{S}-\mathrm{D}$ logic is rooted in marketing research, where it gained momentum since its inception by the landmark study of Vargo and Lusch [2], followed by further amendments $[3,4]$. We synthesis knowledge on S-D logic on four levels, which reflect its descriptive and prescriptive nature (see Fig. 1).

S-D logic has been introduced through descriptive theoretical assumptions, which are formulated as meta-theoretical foundations of S-D logic (Level I) [5, 35]. Subsequently, scholars captured these foundations in a set of S-D logic's foundational premises to explicate S-D logic's worldview (Level II) [2-4]. Later, scholars captured managerial implications of S-D logic's theoretical foundations in real-world practices. This endeavour resulted in a set of derivative propositions that inform practitioners on how to compete in an S-D logic orientation (Level III) [36]. Levels I to III are offered by seminal S-D logic literature. They provide descriptive knowledge to explicate S-D logic with an increasing degree of applicability in practice. Drawing on these three 


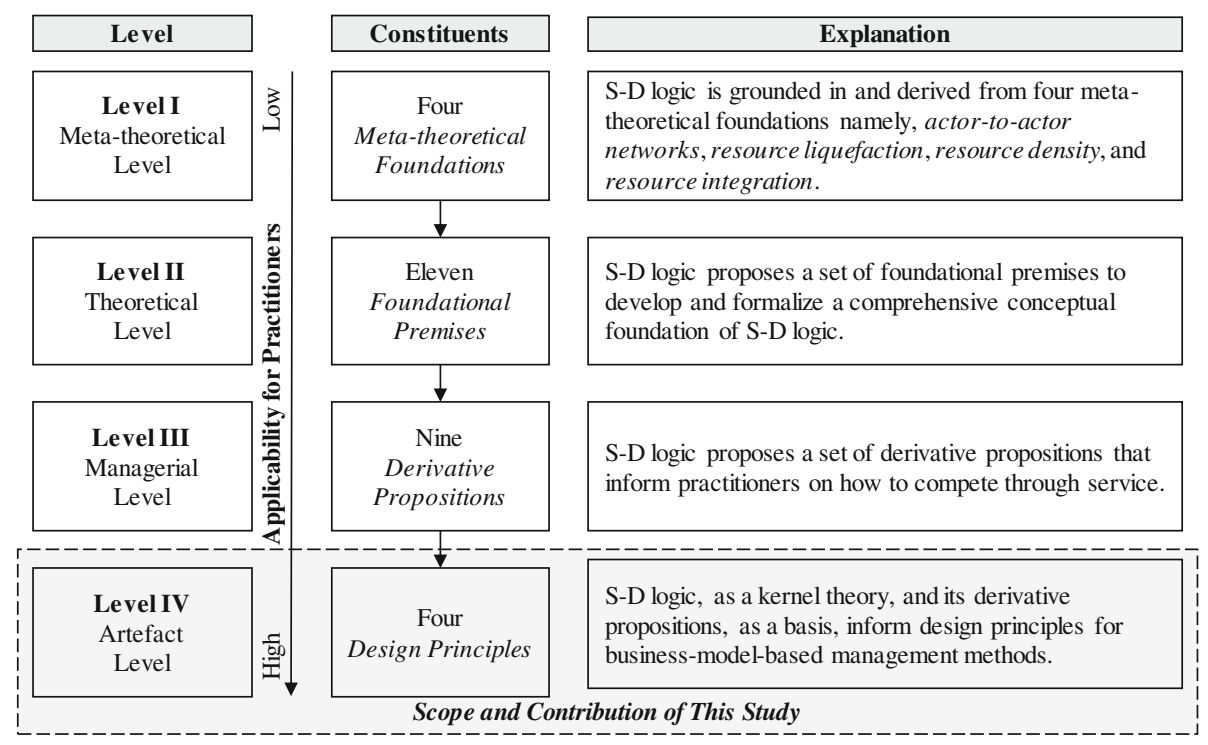

Fig. 1. Service-dominant logic: from descriptive to prescriptive knowledge

levels, we position our study as one step further in translating S-D logic's descriptive basis into prescriptive means in our phenomenon of interest. The central outcome of this design science research (DSR) is thus prescriptive knowledge in the form of design principles for BMBM methods (Level IV). Emphasizing the move from descriptive to prescriptive knowledge, Fig. 1 summarizes these levels; each of which is briefly explained below. Further, building on the seminal S-D logic studies, Table 1 shows the relation between constituents of Level I, II, and III.

Table 1. Service-dominant logic: the relations between meta-theoretical foundations, foundational premises, and derivative propositions (with relations in brackets)

\begin{tabular}{|c|c|c|}
\hline $\begin{array}{l}\text { Meta-theoretical foundations } \\
\text { (MFs) [5] }\end{array}$ & $\begin{array}{l}\text { Foundational premises (FPs) } \\
{[2-4] \text { in association to MFs [5] }}\end{array}$ & $\begin{array}{l}\text { Derivative propositions [36] in } \\
\text { association to FPs }[2-4]\end{array}$ \\
\hline \multirow[t]{2}{*}{$\begin{array}{l}\text { MF1 (Actor-to-Actor- } \\
\text { Networks). S-D logic draws on a } \\
\text { network-centric actor-to-actor } \\
\text { generalization }\end{array}$} & $\begin{array}{l}\text { FP1. Service is the fundamental } \\
\text { basis of exchange }(M F 1)\end{array}$ & $\begin{array}{l}\text { DP1. Competitive advantage is a } \\
\text { function of how one firm applies } \\
\text { its operant resources to meet the } \\
\text { needs of the customer relative to } \\
\text { how another firm applies its } \\
\text { operant resources (FP1, FP4) }\end{array}$ \\
\hline & $\begin{array}{l}\text { FP2. Indirect exchange masks the } \\
\text { fundamental basis of exchange } \\
(M F 1, M F 3)\end{array}$ & $\begin{array}{l}\text { DP2. Collaborative competence is } \\
\text { a primary determinant of a firm's } \\
\text { acquiring the knowledge for } \\
\text { competitive advantage ( } F P 4 \text {, } \\
F P 9)\end{array}$ \\
\hline $\begin{array}{l}\text { MF2 (Resource Liquefaction). } \\
\text { S-D logic draws on the }\end{array}$ & $\begin{array}{l}\text { FP3. Goods are distribution } \\
\text { mechanisms for service provision } \\
(M F 3)\end{array}$ & $\begin{array}{l}\text { DP3. The continued ascendance } \\
\text { of IT with associated decrease in } \\
\text { communication and computation }\end{array}$ \\
\hline
\end{tabular}


Table 1. (continued)

\begin{tabular}{|c|c|c|}
\hline $\begin{array}{l}\text { Meta-theoretical foundations } \\
\text { (MFs) [5] }\end{array}$ & $\begin{array}{l}\text { Foundational premises (FPs) } \\
{[2-4] \text { in association to MFs [5] }}\end{array}$ & $\begin{array}{l}\text { Derivative propositions [36] in } \\
\text { association to FPs }[2-4]\end{array}$ \\
\hline \multirow[t]{2}{*}{$\begin{array}{l}\text { decoupling of information from } \\
\text { its related physical form or device }\end{array}$} & & $\begin{array}{l}\text { costs, provides firms opportunities } \\
\text { for increased competitive } \\
\text { advantage through innovative } \\
\text { collaboration }(F P 6, F P 8)\end{array}$ \\
\hline & $\begin{array}{l}\text { FP4. Operant resources are the } \\
\text { fundamental source of strategic } \\
\text { benefit }(M F 2)\end{array}$ & $\begin{array}{l}\text { DP4. Firms gain competitive } \\
\text { advantage by engaging customers } \\
\text { and value network partners in } \\
\text { co-creation and co-production } \\
\text { activities }(F P 6, F P 9)\end{array}$ \\
\hline \multirow[t]{2}{*}{$\begin{array}{l}\text { MF3 (Resource Density). S-D } \\
\text { logic draws on an effective and } \\
\text { efficient mobilization of } \\
\text { contextually relevant knowledge }\end{array}$} & $\begin{array}{l}\text { FP5. All economies are service } \\
\text { economies }(M F 1)\end{array}$ & $\begin{array}{l}\text { DP5. Understanding how the } \\
\text { customer uniquely integrates and } \\
\text { experiences service-related } \\
\text { resources (both private and } \\
\text { public) is a source of competitive } \\
\text { advantage through innovation } \\
(F P 6, F P 8, F P 9)\end{array}$ \\
\hline & $\begin{array}{l}\text { FP6. Value is co-created by } \\
\text { multiple actors, always including } \\
\text { the beneficiary }(M F 1, M F 4)\end{array}$ & $\begin{array}{l}\text { DP6. Providing service } \\
\text { co-production opportunities and } \\
\text { resources consistent with the } \\
\text { customer's desired level of } \\
\text { involvement leads to improved } \\
\text { competitive advantage through } \\
\text { enhanced customer experience } \\
(F P 6, F P 8, F P 9)\end{array}$ \\
\hline \multirow[t]{5}{*}{$\begin{array}{l}\text { MF4 (Resource Integration). } \\
\text { S-D logic draws on the view that } \\
\text { all social and economic actors as } \\
\text { resource integrators }\end{array}$} & $\begin{array}{l}\text { FP7. Actors cannot deliver value } \\
\text { but can participate in the creation } \\
\text { and offering of value propositions } \\
(M F 1)\end{array}$ & $\begin{array}{l}\text { DP7. Firms can compete more } \\
\text { effectively through the adoption } \\
\text { of collaboratively developed, } \\
\text { risk-based pricing value } \\
\text { propositions }(F P 6, F P 7)\end{array}$ \\
\hline & $\begin{array}{l}\text { FP8. A service-centered view is } \\
\text { inherently beneficiary oriented } \\
\text { and relational }(M F 4)\end{array}$ & $\begin{array}{l}\text { DP8. The value network member } \\
\text { that is the prime integrator is in a } \\
\text { stronger competitive position. The } \\
\text { retailer is generally in the best } \\
\text { position to become the prime } \\
\text { integrator }(F P 1, F P 4, F P 9)\end{array}$ \\
\hline & $\begin{array}{l}\text { FP9. All social and economic } \\
\text { actors are resource integrators } \\
(M F 1, M F 4)\end{array}$ & $\begin{array}{l}\text { DP9. Firms that treat their } \\
\text { employees as operant resources } \\
\text { will be able to develop more } \\
\text { innovative knowledge and skills } \\
\text { and thus gain competitive } \\
\text { advantage (FP4) }\end{array}$ \\
\hline & $\begin{array}{l}\text { FP10. Value is always uniquely } \\
\text { and phenomenologically } \\
\text { determined by the beneficiary } \\
(M F 4)\end{array}$ & \\
\hline & $\begin{array}{l}\text { FP11. Value co-creation is } \\
\text { coordinated through } \\
\text { actor-generated institutions and } \\
\text { institutional arrangements (MF1, } \\
M F 4 \text { ) }\end{array}$ & \\
\hline
\end{tabular}


Meta-theoretical Foundations (Level I). On a meta-theoretical level, S-D logic is grounded in four meta-theoretical foundations namely, actor-to-actor networks, resource liquefaction, resource density, and resource integration [5]. Actor-to-actornetworks emphasizes a shift from one-way process of value exchange in traditional supply chains (i.e., neoclassical industrial perspective) to a collaborative process of value co-creation in service ecosystems (i.e., network-centric perspective). Resource liquefaction describes the shift from information coupled to physical matter to digitized, decoupled, and more useful information. Resource density emphasizes a shift from ineffective /-efficient mobilization of resources for integration at a given time and place to mobilization of an ideal combination of relevant resources in the most effective/efficient way for a particular situation. Resource integration underscores a shift from the production of fixed asset goods to the integration of specialized resources into complex services.

Foundational Premises (Level II). On a theoretical level, Vargo and Lusch proposed $\underline{[2]}$ - and further made amendments on [3, 4] - a set of foundational premises (FPs) for S-D logic to distinguish it from G-D logic. This effort has culminated in eleven FPs [4], which explicate the ontological basis of S-D logic and which are related to S-D logic's meta-theoretical foundations (see Table 1). Overall, in promoting foundational premises, S-D logic re-conceptualizes service (the process of applying specialized competencies for the benefit of and in conjunction with another actor), exchange (not the exchange of outputs but the exchange of the performance of specialized activities), value (occurs when the offering is useful to service beneficiary), and resource (anything an actor can draw on for support) [5].

Regarding resource, S-D logic distinguishes operand and operant resources. Operand resources refer to tangible, static, and passive components of goods that actors employ to obtain support [2]. In S-D logic, they are seen as "vehicles for service provision, rather than primary to exchange and value creation" [37, p. 374]. Conversely, operant resources refer to intangible, dynamic, and active resources (e.g., human knowledge, skill, and experience) that act on other resources [2]. In S-D logic, operant resources have a pivotal role since they are seen as "the fundamental source of competitive advantage" [3, p. 7]. S-D logic perceives information technology (IT) artefacts as both operand and operant resources as they not only facilitate service exchange among actors, but also trigger value co-creation activities and processes [5].

Regarding value, recent literature [29, 38] extracts co-production and value-in-use as the primary theoretical constructs of value. In co-production, value accrues through mutually integrating the organization's, partners', and targeted customers' resources before the service usage time [39]. Conversely, in value-in-use, value accrues through a process of consumption during the actual usage time by the customer [38].

Derivative Propositions (Level III). On a managerial level, building on foundational premises (FPs) of S-D logic [4], Lusch et al. [36] derive nine propositions as the practical implications of the FPs to inform practitioners on how to compete in the real world with an S-D logic orientation (see Table 1). As a practical approach, the derivative propositions' overall theme is to more successfully innovate and compete through service thinking. The derivative propositions start from the premise that in 
order to "survive and prosper in a networked economy, the organization must learn how to be a vital and sustaining part of the value network" [35, p. 21].

Artefact (Level IV). As a new level proposed by the study at hand, this level concerns the development of artefacts that help practitioners exercising the promoted service thinking by S-D logic. As one step in this level, we draw on Lusch et al.'s [36] derivative propositions to derive design principles for our phenomenon of interest i.e., business-model-based management methods.

Extant research has already started incorporating network- and customer-oriented views in BM research [17]. While some studies introduce networks and partnerships in $\mathrm{BM}$ representation [40] or emphasize the importance of customers in BM design [6, 41], others lay emphasis on management tool to control the value distribution in joint value creation [40, 42]. These endeavours demonstrate the ever-increasing importance of S-D logic's theoretical constituents in BM research. Nevertheless, the focus of our study is on the design of management methods, which are informed by the BM concept and can be applied to realize the shift to S-D logic.

\section{Research Methodology}

To systematically develop design principles, we opt for Sonnenberg and vom Brocke's [43, p. 392] cyclic DSR process, which is extended by Abraham et al. [44]. It represents a step-by-step and well-structured DSR process to cyclically build and evaluate DSR artefacts from scratch and independent of the domain of interest. The cyclic DSR process (i) incorporates a design-evaluate-construct-evaluate pattern; and (ii) includes the DSR activities namely, problem identification, design, construction, and use followed by four distinct corresponding evaluation activities referred to as Eval1 to Eval4. We employ the cyclic DSR process due to its continuous assessment of the progress achieved in the DSR process [43, p. 390, 44]. That is, the employed methodology ensures multiple evaluation episodes throughout a single iteration of a DSR process. Table 2 summarizes the DSR activities that we conduct to develop our targeted principles. In this section, we sequentially explicate how the instantiation of the four stages has led to design principles for BMBM methods from the perspective of $S-D$ logic.

I. Problem Identification and Eval1. This research has been conducted in adjacency to an R\&D project at SAP, a world leading business software provider [12]. This project follows a co-innovation format with 20 senior executives of European multi-national enterprises. It aims at iteratively designing consultancy services and software products for BM design and innovation. Its application in consulting projects, workshops, and trainings revealed that although managers are provided with the means to innovate and develop BMs, they severely struggle in efficiently and effectively designing management methods based on the BM concept (PROBLEM IDENTIFICATION). Consequently, we reviewed extant $\mathrm{BM}$ literature, which uncovered a lack of understanding and guiding the design of BMBM methods. To ensure that the stated problem is not only academically relevant, but also meaningful for practitioners, we conducted a one-hour focus group with BM experts and the senior executives. The semi-structured focus group discussion 
Table 2. The applied build and evaluation activities of the cyclic DSR process in our design principles development [adapted from 43, 44]

\begin{tabular}{|c|c|c|c|}
\hline Activity & Purpose of Activity & Applied Method & Output \\
\hline $\begin{array}{l}\text { 1.1. PROBLEM } \\
\text { IDENTIFICATION }\end{array}$ & $\begin{array}{l}\text { Selecting and formulating } \\
\text { a problem }\end{array}$ & $\begin{array}{l}\text { Review of a Practi- } \\
\text { tioner Initiative }\end{array}$ & \multirow{2}{*}{$\begin{array}{l}\text { Justified Problem Statement: } \\
\text { Practitioners lack guidance to efficiently and effec- } \\
\text { tively design business-model-based management } \\
\text { methods. }\end{array}$} \\
\hline 1.2. EVAL1 & $\begin{array}{l}\text { Ensuring that the stated } \\
\text { problem is meaningful }\end{array}$ & $\begin{array}{l}\text { Literature Review, } \\
\text { Focus Group }\end{array}$ & \\
\hline 2.1. DESIGN & $\begin{array}{l}\text { Constructing an artefact } \\
\text { design for the stated prob- } \\
\text { lem }\end{array}$ & $\begin{array}{l}\text { Literature Review, } \\
\text { Logical Reasoning }\end{array}$ & \multirow{2}{*}{$\begin{array}{l}\text { Validated Design Specification: } \\
\text { Employing S-D logic and drawing on its nine deriva- } \\
\text { tive propositions to derive design principles for busi- } \\
\text { ness-model-based management methods. }\end{array}$} \\
\hline 2.2. EVAL2 & $\begin{array}{l}\text { Showing that an artefact } \\
\text { design progresses to a so- } \\
\text { lution of the stated prob- } \\
\text { lem }\end{array}$ & $\begin{array}{l}\text { Logical Reasoning, } \\
\text { Demonstration }\end{array}$ & \\
\hline $\begin{array}{l}\text { 3.1. CONSTRUC- } \\
\text { TION }\end{array}$ & $\begin{array}{l}\text { Constructing a prototypi- } \\
\text { cal artefact instance }\end{array}$ & $\begin{array}{l}\text { Expert Workshop, } \\
\text { Logical Reasoning }\end{array}$ & \multirow{2}{*}{$\begin{array}{l}\text { Validated Artefact Instance in an Artificial Setting: } \\
\text { Validating the prototypically constructed design prin- } \\
\text { ciples against practitioners' requirements as well as } \\
\text { the BM concept. }\end{array}$} \\
\hline 3.2. EVAL3 & $\begin{array}{l}\text { Demonstrating if and how } \\
\text { well the artefact is de- } \\
\text { signed }\end{array}$ & BM Expert Interview & \\
\hline 4.1. USE & $\begin{array}{l}\text { Constructing a complete } \\
\text { artefact instance }\end{array}$ & $\begin{array}{l}\text { Literature Review, } \\
\text { Logical Reasoning }\end{array}$ & \multirow{2}{*}{$\begin{array}{l}\text { Validated Artefact Instance in a Partially Natural- } \\
\text { istic Setting: } \\
\text { Validating the fully-constructed design principles } \\
\text { with real users. }\end{array}$} \\
\hline 4.2. EVAL4 & $\begin{array}{l}\text { Showing that the artefact } \\
\text { is both applicable and use- } \\
\text { ful in practice }\end{array}$ & Focus Group & \\
\hline
\end{tabular}

revealed that practitioners acknowledge the lack of design guidance for BMBM methods in dealing with the contemporary business environment (EVALl).

II. Design and Eval2. After $E_{V A L} 1$ we opted for S-D logic as a kernel theory. We reviewed prevalent S-D logic literature ${ }^{1}$ to inform two major design decisions. First, drawing on seminal S-D logic studies [2-5], we logically reason that S-D logic is an appropriate perspective on BMBM methods because S-D logic explicates how an organization ought to "do business" and compete [1]. Second, S-D logic has been formulated on a meta-theoretical [5], theoretical [4], and managerial [36] level (see Sect. 2). However, extant research underserves a prescriptive guidance in applying S-D logic, in general, and in designing BMBM methods from an S-D logic perspective in particular. Therefore, we opted for deriving design principles, as an appropriate DSR artefact [47, 48], for BMBM methods from S-D logic's nine derivative propositions [36] $\left(D_{E S I G N)}\right.$. These two design decisions, the derivative propositions (as kernel theory) and design principles (as DSR artefacts), were evaluated in a 90-min demonstration with BM experts and five executives of major European multi-national enterprises (EVAL2). EVAL2 revealed that linking S-D logic and the BM concept is timely, relevant, and useful. This

\footnotetext{
${ }^{1}$ We include relevant studies on S-D logic that are published in world leading marketing journals. Precisely, we include eleven marketing journals that are ranked (world) leading (tagged with*) by at least one of the ratings included in the $57^{\text {th }}$ Harzing Journal Quality List (2016). We search in the Business Source Premier database employing the EBSCOhost search engine since S-D logic's inaugural year 2004 [2]. The 30 selected papers have the phrases "service-dominant", "service logic", or "dominant logic" in title, abstract, or keywords. In addition, we include studies on and/or using S-D logic that are published in the AIS basket-of-eight journals. This adds another 15 papers, most of which are part of the MISQ special issues on "Service Innovation in the Digital Age" [45] and on "Co-creating IT Value" [46].
} 
is because, first, the BM concept-alike S-D logic-is inherently focused beyond the organization and concerns its network comprising suppliers, strategic partners, customers, competitors, and regulators [14, 15]. Second, in designing and implementing service-based business, the BM concept has been adopted as an immediate reflection and realization of S-D logic in real-world organizational practices [1, 49, 50].

III. Construction and Eval3. The design principles were then prototypically constructed. This process was kicked-off by an expert workshop comprising three of the software provider's BM experts, two of which are co-authors of the study at hand. The expert workshop participants discussed in-depth why, whether, and how design principles can be derived from S-D logic's nine derivative propositions [36] (CONSTRUC$T I O N)$. To validate and improve the initial design principle instances in an artificial setting, another $60 \mathrm{~min}$ semi-structured expert interview was conducted with BM experts unfamiliar with S-D logic. It revealed that the prototypical formulation of the four initial design principles was immature for the following reasons: (1) too abstract and non-applicable by managers due to overemphasizing theoretical and abstract S-D logic language; (2) insufficiently linked with and integrated into the BM concept, and (3) too unstructured in their presentation. Shortcomings (1) and (2) were addressed by specifically employing language that practitioners use in reasoning about service and $\mathrm{BMs}$, and tightly integrating this language to S-D logic and BM thinking. Shortcoming (3) was addressed by employing a threefold structure for the systematic presentation of design principles $[51,52]$ comprising the design principle's statement, rationale, and implications (EVAL3).

IV. Use and Eval4. The fourth step of fully constructing and using the final design principles to evaluate their usefulness and applicability in a naturalistic setting is still in the process of iterative refinement. To this, we accounted for the three realities (real tasks, real systems, and real users) [43, p. 396] and conducted a one-hour semistructured focus group to discuss and evaluate the use of design principles in the early stage of designing a BMBM method with potential real users. This discussion comprised two BM experts and four executives of major multi-national European enterprises. The first iteration of this phase revealed that the initially proposed four design principles are basically useful, but require further reduction of abstractness and more fine-granular explication of their implications. This shortcoming was addressed by explicitly employing vocabulary that the focus group's attendees deem useful for the design principles' purpose (EVAL4).

\section{Design Principles for Business-Model-based Management}

This section describes the derived design principles for BM-based management (BMBM) methods, which are informed by the BM concept and can be applied to realize the shift to S-D logic. Our intent here is not only to capture the general design guidance for BMBM methods, but also to illustrate their implications in organizations. Table 3 summarizes the four design principles. Each principle is discussed in detail following a tripartite structure comprising the design principle's statement, rationale, 
and implications $[51,52]$. We use the notion $P n$ to refer to the $n^{\text {th }}$ derivative proposition of S-D logic [36, p. 8] and present the respective proposition in italics.

Table 3. Design principles for business-model-based management methods

\begin{tabular}{|c|c|c|}
\hline Principle & Description & $\begin{array}{l}\text { Association to S-D } \\
\text { logic's derivative } \\
\text { propositions [36] }\end{array}$ \\
\hline $\begin{array}{l}\text { Principle 1: } \\
\text { Ecosystem-oriented } \\
\text { management }\end{array}$ & $\begin{array}{l}\text { BMBM methods should account (i) for orchestration of } \\
\text { specific actor roles in a service ecosystem; (ii) for } \\
\text { positioning of an organization's role as focal } \\
\text { orchestrator in a service ecosystem; as well as (iii) for } \\
\text { sharing of economic risks, costs, and revenues among a } \\
\text { multitude of various actor roles in a service ecosystem }\end{array}$ & $\mathrm{P} 2, \mathrm{P} 7, \mathrm{P} 8$ \\
\hline $\begin{array}{l}\text { Principle } 2 \text { : } \\
\text { Technology-oriented } \\
\text { management }\end{array}$ & $\begin{array}{l}\text { BMBM methods should account (i) for the application } \\
\text { of digital infrastructures; (ii) for decoupling } \\
\text { informational assets from products and facilitate their } \\
\text { commercialization; as well as (iii) for driving value } \\
\text { creation through digital channels and digitally enhanced } \\
\text { customer relationships }\end{array}$ & P3 \\
\hline $\begin{array}{l}\text { Principle 3: } \\
\text { Mobilization-oriented } \\
\text { management }\end{array}$ & $\begin{array}{l}\text { BMBM methods should account (i) for the mobilization } \\
\text { of operant resources; (ii) for uncovering and utilizing } \\
\text { internal knowledge for new fields of business; as well as } \\
\text { (iii) for identifying and activating operant resources of } \\
\text { partners and customers in the service ecosystem }\end{array}$ & $\mathrm{P} 1, \mathrm{P} 4, \mathrm{P} 9$ \\
\hline $\begin{array}{l}\text { Principle } 4 \text { : } \\
\text { Co-creation-oriented } \\
\text { management }\end{array}$ & $\begin{array}{l}\text { BMBM methods should account (i) for customer } \\
\text { involvement, enhancing value-in-use and sustaining } \\
\text { their engagement; (ii) for reflecting on value co-creation } \\
\text { through customer journeys as dynamic interaction; as } \\
\text { well as (iii) for recalibrating service bundles to optimize } \\
\text { customer experience }\end{array}$ & P4, P5, P6 \\
\hline
\end{tabular}

\subsection{Principle \#1: Ecosystem-oriented Management}

Statement. BMBM methods leverage the BM concept to facilitate an efficient and effective orchestration of mostly loosely coupled social and economic actors in service ecosystems regarding their specific actor roles.

Rationale. Per S-D logic, collaborative competence is a primary determinant of a firm's acquiring the knowledge for competitive advantage (P2). As a part of the BM concept, an organization's network model (i.e., suppliers, partners, customers, and competitors) [17] helps understand the specific actor roles in a service ecosystem.

Moreover, $P 7$ tells us that firms can compete more effectively through the adoption of collaboratively developed, risk-based pricing value propositions. An organization's revenue model (i.e., revenue streams and pricing mechanisms) and financial model (i.e., financing model, capital model, and cost structure model) [17] are essential component of the BM concept. BMBM methods leverage these to ensure that economic risks, costs, and revenues are fairly shared among the multitude of actor roles. This is a precondition for a service ecosystem to run and evolve in a stable manner. 
Finally, we learn from $P 8$ that the value network member that is the prime integrator is in a stronger competitive position. This proposition first and foremost points to the leading role of the prime integrator in the service ecosystem. Beyond, it concerns the roles of all its members as a function of the prime integrator's BM. Consequently, BMBM methods consider the distribution of power within a service ecosystem in the organization's BM to strengthen its position or become a prime integrator.

Generally, S-D logic underscores that economic exchange always takes place in actor-to-actor networks [5]. Dynamic and co-evolving communities of diverse actors jointly determine the $\mathrm{BM}$ to create and capture new value through both collaboration and competition. While in G-D logic value creation is mainly understood as taking place in the single organization, the very locus of value (co-)creation becomes increasingly diverse and complex in S-D logic's actor-to-actor network orientation. G-D logic considers partners only as resource suppliers, while the central role of customers as value co-creators is ignored. Zott and Amit [24] already pointed to the fundamental role of the BM concept for orchestrating service ecosystems, and, more recently, Leminen et al. [53] have emphasized the role of BMs as a unique means for materializing the opportunities of digital service ecosystems. Prominent BM representations consider service ecosystems implicitly so that the network character only becomes apparent in the interfaces of the focal organization to its immediate partners and customers. However, multi-sided BMs evident in the service economy require more complex network representations. Such network-based BM representations are to guide an ecosystem-oriented management to reflect S-D logic's actor-to-actor network orientation.

Implications. (1) Management methods make use of BM concept to extend their management focus from processes, activities, resources, and practices within their own organization to the coordination and governance of entire service ecosystems; (2) BMs are employed to enable planning and facilitating value co-creation by establishing a variety of roles associated to different actors in the network (e.g., service offeror, service beneficiary, ideator, designer, and intermediary).

\subsection{Principle \#2: Technology-oriented Management}

Statement. BMBM methods leverage IT to increase the efficiency and effectiveness of BMs' function by decoupling physical matter and informational assets, by capturing and sharing data, and by facilitating economic and social interaction.

Rationale. S-D logic advises that the effective application of operant resources is "the fundamental source of competitive advantage" [3, p. 7]. This is particularly true for digital resources. S-D logic emphasizes that the continued ascendance of information technology with associated decrease in communication and computation costs, provides firms opportunities for increased competitive advantage through innovative collaboration (P3). This proposition reflects the growing importance of IT due to its prominent role in digital innovation [54]. Through the ascendance of IT, information is no longer embedded in physical matter or devices. Conversely, it can be decoupled and 
shared independent of the cost and time of physical transport. The BM concept is a means for materializing such opportunities of digitalization [8] through comprising IT in the design, commercialization, and monetarization of service [45]. Management methods should assume such a growing entwinement of business and technology. This is reflected in overhauled BMs, with technology-enabled value propositions at their core, based on the opportunities of digital infrastructures [55-57]. The design principle of technology-oriented management is consistent with service science, emphasizing the fundamentally changed role of IT [5] that enables a multitude of novel and complex service-based BMs [1] to utilize the opportunities of the networked service economy.

Implication. (1) Management methods incorporate IT and digital resources to design innovative value propositions comprising operant resources (e.g., data, information, knowledge, experience, skills); (2) they particularly focus on the decoupling of information and matter, the de-linking of ownership and value creation, and the systematic use of IT as means to achieve collaborative competence; (3) they consider digital infrastructure as means to co-create value in service ecosystems.

\subsection{Principle \#3: Mobilization-oriented Management}

Statement. BMBM methods facilitate the access to relevant internal (e.g., employees) and external (e.g., partner) resources and constantly question and renew the existing BM. BMBM methods facilitate resources' mobilization, and consider their combination in the most effective and efficient way for the particular service context.

Rationale. S-D logic states that competitive advantage is a function of how one firm applies its operant resources to meet the needs of the customer relative to how another firm applies its operant resources (P1). The access to particular operant resources enables organizations to differentiate from competitors. Resources are an essential component of the BM, which relates them to the organization's core activities and considers their contribution to the value proposition.

Moreover, P4 explains that firms gain competitive advantage by engaging customers and value network partners in co-creation and co-production activities. Such co-creation and co-production is mainly facilitated by the resources that partners and customers contribute. The BM concept reflects the availability of resources and thus enables the reflection on how they can be mobilized from and to pivotal actors. We refer to resource mobilization as "extending the access to and the use of resources" [ 31 , p. 4]. There is also a relation to previous design principle because digital technologies help mobilize slack resources of partners and customers' resources.

Turning to internal resources, S-D logic asserts: Firms that treat their employees as operant resources will be able to develop more innovative knowledge and skills and thus gain competitive advantage (P9). BMs consider these internal resources but mostly those that are actively used. Latent resources are often neglected despite their potential for future business and provide a main target of internal resource mobilization. In this vein, BMBM methods constantly revisit the existing BM in that they employ partners' and customers' (external) as well as employees' (internal) operant 
resources to create new business. Another major reservoir for new business lies in the mobilization of operan $t$ resources that could not be used due to high transaction or coordination costs in the past. S-D logic motivates to see operant resources as enabler for new business. For instance, Airbnb and Uber make use of the partners' unused apartments, vehicles, and workforce. However, the potential is much larger than these examples.

Implication. (1) Management methods aim at the identification of available but so far mostly unused internal and external resources; (2) they reflect on the utilization of digital technologies to make these resources accessible to be utilized for value co-creation purposes; (3) they use this overview of available resources to analyse the organization's respective advantage in comparison to competitors.

\subsection{Principle \#4: Co-creation-oriented Management}

Statement. BMBM methods leverage the BM concept to establish, extend, and manage the partner and customer interactions rather than to produce goods which are exchanged in a singular transaction. BMBM methods aim at encouraging co-creation interactions by reconciling value propositions, customer relationships, and interaction channels.

Rationale. This principle refers to the core insight of S-D logic that firms gain competitive advantage by engaging customers and value network partners in co-creation [...] activities (P4). Such value co-creation allows for longer and more intensive interaction between actors (value-in-use) than via the traditional production and delivery of goods (value-in-exchange). The idea of servitization, that is, the replacement of offering of products by related but often more effective services, is the perfect paragon in this respect. BMs consider the respective elements for interaction and can therefore be used to systematize the interaction.

Turning particularly to the customer side, understanding how the customer uniquely integrates and experiences service-related resources (both private and public) is a source of competitive advantage through innovation (P5). BMs use value proposition and customer journeys [58] to understand the way customers use services in an integrated way, which helps better design combined services and better address the particular customer context.

A final aspect in this respect is that providing service co-production opportunities and resources consistent with the customer's desired level of involvement leads to improved competitive advantage through enhanced customer experience (P6). In addition to the previous two propositions, $P 6$ points to the motivation of customers to take part in value co-creation processes and activities. BMs consider such motivations in customer journeys, in which they analyse the specific interaction with customers, reflecting on their thoughts and motivations to engage in such interactions.

Whilst economic actors have always integrated their resources, most of this integration took place inside organizations. Recently pervasive digitalization of organizational life has led to massive integration of resources beyond organizational 
boundaries, which expands the integration over the organizational boundaries [5, 34, 45]. One of the central advantages of such value co-creation is that it allows companies to address customer needs in the most efficient way. For example, car sharing does not only entail making a car available, but also requires to place the most suitable car at the right time at the right place at the optimal disposal of customers. Services that provide such information do not necessarily belong to the car provider. Management methods that use the BM concept to improve the value-in-use can take advantage of the opportunity of today's service economy.

Implication. (1) Management methods analyse the customers' objectives and their available resources to facilitate the interaction in the business ecosystem with the goal to enhance customers' value-in-use; (2) to this end and in arranging the tripartite of value propositions, customer relationships, and channels of interaction, management methods aim at the optimal interaction with customers and partners to obtain the most desirable combination of resources for a contextually required service; (3) based on BM tools such as customer journeys, BMs move away from static value propositions to dynamic interaction designs to elaborate how customers can be engaged in value co-creation and what their motivation is to do so.

\section{Discussion and Conclusion}

The central outcome of this design science research is prescriptive knowledge in the form of four design principles namely, ecosystem-, technology-, mobilization-, and cocreation-oriented management. The offered design principles guide the design of business-model-based management (BMBM) methods. The principles are built upon service-dominant (S-D) logic's derivative propositions [36]—representing managerial implications of S-D logic - and grounded in the business model (BM) concept. As such, the offered principles account for S-D logic and the BM concept to reflect the most foundational aspects that contemporary organizations have to consider in their management methods to compete and prosper in a networked, digital service economy [59]. The underlying assumption is that organizations that abide by the offered principles in designing their BMBM methods would effectively compete through service BMs [36].

Contribution. The study's theoretical contribution is twofold. First, it contributes to $B M$ research in using the $\mathrm{BM}$ concept to advance management methods. While extant BM research predominantly lays emphasis on the BM's concept [15], terminology [14], structure [15], representation [60], and management process [16], we use the concept of BM in designing management methods. Such BM-based management methodsparticularly those designed following the offered principles - spotlight (1) the logic of business ecosystems beyond traditional supply and value chains; (2) the pivotal role of information technology as facilitator of novel business logics; (3) operant resources as the fundamental source of competitive BMs; and (4) the processes and activities underpinning value co-creation among actors in the business ecosystem. Second, the extant S-D logic research is dominated by theoretical discourses and lacks factual implications in the real-world organizational practices [61-63]. This research 
contributes to $S$-D logic literature in going one step further in expanding S-D logic beyond the realm of philosophy and theory (see Fig. 1). Thus, we employ S-D logic's descriptive knowledge base to derive principles as applicable knowledge to guide the design of BMBM methods (i.e., prescriptive knowledge).

Implications. Researchers, through the proposed principles, are offered four key themes to more precisely understand antecedents, manifestations, and consequences of novel socio-technical phenomena, such as service-based BMs [1], digital infrastructure [56], or service ecosystems [59,64]. These novel phenomena emerge in the course of a networked and digital service economy [59] and cause major business and technology shifts. This research also provides guidance for managers in the design of a particular class of management methods. Adapting to emergent service and networked economies in current business environments is both relevant and complex for managers. Through applying the offered principles, managers can thus more clearly analyse requirements and design specifications of management methods that adhere to BM and service thinking. This may be especially useful for organizations during early planning and implementation phases of BMBM. Using the principles, managers might anticipate areas of concerns and take appropriate measures in the instantiation of BMBM.

Limitations and Future Research. Interpreting and applying the design principles should be done cautiously due to this research's limitations. First, given the socio-technical nature and the scope of BMBM methods, a naturalistic evaluation comprising real tasks, real systems, and real users [43, p. 396] is resource consuming. While a first iteration of such an evaluation has been conducted (see Sect. 3), the principles' usefulness can be further enhanced through applying the principles to a concrete instantiation of a BMBM method in a naturalistic setting [43]. Second, since the principles remain purposefully abstract for context-independent instantiations of BMBM methods, they provide limited actionable advice. That is, we propose one step further in translating S-D logic's descriptive knowledge base into prescriptive means for a novel class of management methods (i.e., BM-based). However, we do not provide detailed guidance on how to exactly design BMBM methods or extend extant management methods. Consequently, we encourage future research to shed further light on (i) how to realize the principles' implications (see Sect. 4) and (ii) the dynamics and the process of a reorientation in extant management methods toward BMBM methods. A first actionable step in BMBM can be representing to what extend a customer co-determines the cost structure, revenue model, and revenue sharing [49, 50]. Moreover, BMBM methods need to represent how an organization's resources and processes are integrated into a customer's resources and processes $[49,50]$. Third, the offered principles are not exhaustive. Given the highly aggregated problem class of how to methodologically manage an organization, there are complementary theoretical lenses that help advancing the principles. Drawing on S-D logic's resource orientation, resource-based view (RBV) and resource dependence theory (RDT) can be considered as complementary theoretical bases. Therefore, in advancing the offered principles, we encourage future research to employ RBV in, for instance, identifying and exploiting valuable, rare, inimitable, and non-substitutable operant resources inside and outside the organization [65]. Similarly, prospective research can employ RDT to shed light on, 
for instance, how BMBM methods can help organizations in reducing environmental interdependence and uncertainty with appropriate BMs [66].

Conclusion. The rise of digital and ecosystemic business leads to new demands in business management. BMs play an increasingly pivotal role in such business contexts, which suggests that they are to be placed at the centre of new management methods. The latter requires a concise set of design principles for designing such methods. Relying on the descriptive insights by S-D logic on the requirements of a service business, these design principles deal with the core area of future organizational management such as orchestrating ecosystems, employing operant resources, novel logics of mobilizing resources between actors, and re-bundling of resources for novel value propositions through value co-creation.

Acknowledgements. This work has been supported by the Swiss National Science Foundation (SNSF).

\section{References}

1. Maglio, P.P., Spohrer, J.: A service science perspective on business model innovation. Ind. Mark. Manag. 42, 665-670 (2013)

2. Vargo, S.L., Lusch, R.F.: Evolving to a new dominant logic for marketing. J. Mark. 68, 1-17 (2004)

3. Vargo, S.L., Lusch, R.F.: Service-dominant logic: continuing the evolution. J. Acad. Mark. Sci. 36, 1-10 (2008)

4. Vargo, S.L., Lusch, R.F.: Institutions and axioms: an extension and update of service-dominant logic. J. Acad. Mark. Sci. 44, 5-23 (2016)

5. Lusch, R.F., Nambisan, S.: Service innovation: a service-dominant logic perspective. MIS Q. 39, 155-175 (2015)

6. Prahalad, C.K., Ramaswamy, V.: Co-creating unique value with customers. Strategy Leadersh. 32, 4-9 (2004)

7. Macdonald, E.K., Kleinaltenkamp, M., Wilson, H.N.: How business customers judge solutions: solution quality and value in use. J. Mark. 80, 96-120 (2016)

8. Loebbecke, C., Picot, A.: Reflections on societal and business model transformation arising from digitization and big data analytics: a research agenda. J. Strateg. Inf. Syst. 24, 149-157 (2015)

9. Bharadwaj, A., El Sawy, O.A., Pavlou, P.A., Venkatraman, N.: Digital business strategy: toward a next generation of insights. MIS Q. 37, 471-482 (2013)

10. Bharadwaj, A., El Sawy, O.A., Pavlou, P.A., Venkatraman, N.: Visions and voices on emerging challenges in digital business strategy. MIS Q. 37, 633-661 (2013)

11. Tallon, P.P.: A service science perspective on strategic choice, IT, and performance in U.S. banking. J. Manag. Inf. Syst. 26, 219-252 (2010)

12. Eisert, U., Doll, J.: Business model based management: bridging the gap between strategy and daily business. $360^{\circ}$ - Bus. Transform. J. 15, 15-28 (2015)

13. Terrenghi, N., Schwarz, J., Legner, C., Eisert, U.: Business model management: current practices, required activities and IT support. In: Proceedings of the 13th Internationale Tagung Wirtschaftsinformatik (WI 2017), pp. 972-986, St. Gallen (2017) 
14. Zott, C., Amit, R., Massa, L.: The business model: recent developments and future research. J. Manag. 37, 1019-1042 (2011)

15. Hedman, J., Kalling, T.: The business model concept: theoretical underpinnings and empirical illustrations. Eur. J. Inf. Syst. 12, 49-59 (2003)

16. Hienerth, C., Keinz, P., Lettl, C.: Exploring the nature and implementation process of user-centric business models. Long Range Plann. 44, 344-374 (2011)

17. Wirtz, B.W., Pistoia, A., Ullrich, S., Göttel, V.: Business models: origin, development and future research perspectives. Long Range Plann. 49, 36-54 (2016)

18. Tsalgatidou, A., Pitoura, E.: Business models and transactions in mobile electronic commerce: requirements and properties. Comput. Netw. 37, 221-236 (2001)

19. Osterwalder, A., Pigneur, Y., Tucci, C.L.: Clarifying business models: origins, present, and future of the concept. Commun. Assoc. Inf. Syst. 16, 1 (2005)

20. Veit, D., Clemons, E., Benlian, A., Buxmann, P., Hess, T., Kundisch, D., Leimeister, J.M., Loos, P., Spann, M.: Business models. Bus. Inf. Syst. Eng. 6, 45-53 (2014)

21. Peters, C., Blohm, I., Leimeister, J.M.: Anatomy of successful business models for complex services: insights from the telemedicine field. J. Manag. Inf. Syst. 32, 75-104 (2015)

22. Ebel, P., Bretschneider, U., Leimeister, J.M.: Leveraging virtual business model innovation: a framework for designing business model development tools. Inf. Syst. J. 26, 519-550 (2016)

23. Giessmann, A., Legner, C.: Designing business models for cloud platforms. Inf. Syst. J. 26, 551-579 (2016)

24. Zott, C., Amit, R.: The fit between product market strategy and business model: implications for firm performance. Strateg. Manag. J. 29, 1-26 (2008)

25. Teece, D.J.: Business models, business strategy and innovation. Long Range Plann. 43, 172$194(2010)$

26. Richardson, J.: The business model: an integrative framework for strategy execution. Strateg. Change 17, 133-144 (2008)

27. Massa, L., Tucci, C., Afuah, A.: A critical assessment of business model research. Acad. Manag. Ann. 11(1), 73-104 (2017). doi:https://doi.org/10.5465/annals.2014.0072

28. Afuah, A., Allan, A.: Business Models: A Strategic Management Approach. Mcgraw Hill Book Co, New York (2003)

29. Galvagno, M., Dalli, D.: Theory of value co-creation: a systematic literature review. Manag. Serv. Qual. Int. J. 24, 643-683 (2014)

30. Vargo, S.L., Lusch, R.F., Akaka, M.A.: Advancing service science with service-dominant logic. In: Maglio, P.P., Kieliszewski, C.A., Spohrer, J.C. (eds.) Handbook of Service Science, pp. 133-156. Springer, New York (2010)

31. Böhmann, T., Leimeister, J.M., Möslein, K.: Service-systems-engineering. Wirtschaftsinformatik 56, 83-90 (2014)

32. Maglio, P.P., Vargo, S.L., Caswell, N., Spohrer, J.: The service system is the basic abstraction of service science. Inf. Syst. E-Bus. Manag. 7, 395-406 (2009)

33. Alter, S.: Challenges for service science. J. Inf. Technol. Theory Appl. 13, 22 (2012)

34. Srivastava, S.C., Shainesh, G.: Bridging the service divide through digitally enabled service innovations: evidence from indian healthcare service providers. MIS Q. 39, 245-267 (2015)

35. Lusch, R.F., Vargo, S.L., Tanniru, M.: Service, value networks and learning. J. Acad. Mark. Sci. 38, 19-31 (2010)

36. Lusch, R.F., Vargo, S.L., O’Brien, M.: Competing through service: Insights from service-dominant logic. J. Retail. 83, 5-18 (2007)

37. Pels, J., Vargo, S.L.: Toward a transcending conceptualization of relationship: a service-dominant logic perspective. J. Bus. Ind. Mark. 24, 373-379 (2009) 
38. Ranjan, K., Read, S.: Value co-creation: concept and measurement. J. Acad. Mark. Sci. 44, 290-315 (2016)

39. Etgar, M.: A descriptive model of the consumer co-production process. J. Acad. Mark. Sci. 36, 97-108 (2008)

40. Nenonen, S., Storbacka, K.: Business model design: conceptualizing networked value co-creation. Int. J. Qual. Serv. Sci. 2, 43-59 (2010)

41. Yip, G.S.: Using strategy to change your business model. Bus. Strategy Rev. 15, 17-24 (2004)

42. Smedlund, A.: Value cocreation in service platform business models. Serv. Sci. 4, 79-88 (2012)

43. Sonnenberg, C., vom Brocke, J.: Evaluations in the science of the artificial - reconsidering the build-evaluate pattern in design science research. In: Peffers, K., Rothenberger, M., Kuechler, B. (eds.) DESRIST 2012. LNCS, vol. 7286, pp. 381-397. Springer, Heidelberg (2012). doi:10.1007/978-3-642-29863-9_28

44. Abraham, R., Aier, S., Winter, R.: Fail early, fail often: towards coherent feedback loops in design science research evaluation. In: Proceedings of the International Conference on Information Systems - Building a Better World through Information Systems, pp. 24172428. Association for Information Sytems, Auckland (2014)

45. Barrett, M., Davidson, E., Prabhu, J., Vargo, S.L.: Service innovation in the digital age: key contributions and future directions. MIS Q. 39, 135-154 (2015)

46. Grover, V., Kohli, R.: Cocreating IT value: new capabilities and metrics for multifirm environments. MIS Q. 36, 225-232 (2012)

47. Chaturvedi, A.R., Dolk, D.R., Drnevich, P.L.: Design principles for virtual worlds. MIS Q. 35, 673-684 (2011)

48. Yang, L., Su, G., Yuan, H.: Design principles of integrated information platform for emergency responses: the case of 2008 Beijing Olympic Games. Inf. Syst. Res. 23, 761-786 (2012)

49. Zolnowski, A., Böhmann, T.: Customer integration in service business models. In: Proceedings of the 46th Hawaii International Conference on System Sciences, pp. 1103$1112(2013)$

50. Zolnowski, A., Semmann, M., Böhmann, T.: Introducing a co-creation perspective to service business models. In: Proceedings of Enterprise Modelling and Information Systems Architectures (EMISA) 2011, pp. 243-248 (2011)

51. Richardson, G.L., Jackson, B.M., Dickson, G.W.: A principles-based enterprise architecture: lessons from texaco and star enterprise. MIS Q. 14, 385-403 (1990)

52. Aier, S., Fischer, C., Winter, R.: Construction and evaluation of a meta-model for enterprise architecture design principles. In: Bernstein, A., Schwabe, G. (eds.) Proceedings of the 10th International Conference on Wirtschaftsinformatik (WI 2011), Zurich, pp. 637-644 (2011)

53. Leminen, S., Westerlund, M., Rajahonka, M., Siuruainen, R.: Towards IOT ecosystems and business models. In: Andreev, S., Balandin, S., Koucheryavy, Y. (eds.) NEW2AN/ ruSMART -2012. LNCS, vol. 7469, pp. 15-26. Springer, Heidelberg (2012). doi:10.1007/ 978-3-642-32686-8_2

54. Ross, J., Sebastian, I., Beath, C., Mocker, M., Moloney, K., Fonstad, N.: Designing and executing digital strategies. In: ICIS 2016 Proceedings (2016)

55. Hanseth, O., Lyytinen, K.: Design theory for dynamic complexity in information infrastructures: the case of building internet. J. Inf. Technol. 25, 1-19 (2010)

56. Henfridsson, O., Bygstad, B.: The generative mechanisms of digital infrastructure evolution. MIS Q. 37, 907-931 (2013)

57. Tilson, D., Lyytinen, K., Sørensen, C.: Digital infrastructures: the missing IS research agenda. Inf. Syst. Res. 21, 748-759 (2010) 
58. Stickdorn, M., Schwarzenberger, K.: Service design in tourism. Entrep. Tour. Unternehmerisches Denk. Erfolgskonzepte Aus Prax. 2261 (2016)

59. El Sawy, O.A., Malhotra, A., Park, Y., Pavlou, P.A.: Seeking the configurations of digital ecodynamics: it takes three to tango. Inf. Syst. Res. 21, 835-848 (2010)

60. Baden-Fuller, C., Morgan, M.S.: Business models as models. Long Range Plann. 43, 156$171(2010)$

61. Day, G.S.: Achieving advantage with a new dominant logic in "invited commentaries on "evolving to a new dominant logic for marketing'”. J. Mark. 68, 18-27 (2004)

62. Levy, S.J.: How new, how dominant? In: Lusch, R.F., Vargo, S.L. (eds.) The Service-Dominant Logic of Marketing: Dialog, Debate, and Directions, pp. 57-64. M.E. Sharpe, New York (2006)

63. Jain, H., Tanniru, M., Spohrer, J., Hsu, C., Zhao, L., Zhao, L.: ICIS 2007 panel report: bridging service computing and service management: how MIS contributes to service orientation? Commun. Assoc. Inf. Syst. 22, 145 (2007)

64. Akaka, M.A., Vargo, S.L., Lusch, R.F.: An exploration of networks in value cocreation: a service-ecosystems view. Rev. Mark. Res. 9, 13-50 (2012)

65. Wade, M., Hulland, J.: The resource-based view and information systems research: review, extension, and suggestions for future research. MIS Q. 28, 107-142 (2004)

66. Drees, J.M., Heugens, P.P.: Synthesizing and extending resource dependence theory a meta-analysis. J. Manag. 39, 1-33 (2013) 